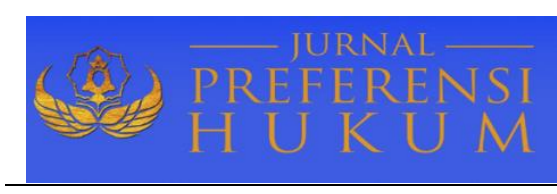

Jurnal Preferensi Hukum | ISSN: 2746-5039

Vol. 2, No. 1 -Februari 2021, Hal. 104-108| Available online at

https://www.ejournal.warmadewa.ac.id/index.php/juprehum

DOI: https://doi.org/10.22225/jph.2.1.3054.104-108

\title{
EKSISTENSI POS BANTUAN HUKUM (POSBAKUM) DI PENGADILAN TATA USAHA NEGARA DENPASAR
}

\author{
Ni Nyoman Gabriella Christiawan Putri, A.A. Sagung Laksmi Dewi, I Nyoman Sutama \\ Fakultas Hukum Universitas Warmadewa, Denpasar-Bali, Indonesia
}

\begin{abstract}
Abstrak
Hukum selalu bereputasi seiring perkembangan zaman, hukum yang baik harus mampu menyesuaikan fungsinya sesuai tuntutan zaman. Tidak sedikit masyarakat yang minim pengetahuan tentang hukum. Oleh sebab itu kegiatan bantuan hukum khususnya bagi masyarakat yang tidak mampu serta awam di bidang hukum semakin luas di masyarakat, yang kini sudah begitu berkembang di Indonesia. Adapun Undang-Undang yang mengatur secara jelas tentang bantuan hukum ialah Undang-Undang Nomor 16 Tahun 2011. Penelitian ini bertujuan untuk menjelaskan kedudukan Pos Bantuan Hukum (Posbakum) dalam memberikan pelayanan di PTUN Denpasar dan menjelaskan fungsi pemberian layanan bantuan hukum di PTUN Denpasar. Metode penelitian yang digunakan penelitian hukum normatif, dengan pendekatan Perundang-Undangan. Sumber data yang digunakan adalah bahan hukum primer dan bahan hukum sekunder seperti peraturan perundang-undangan, teori hukum dan dapat yang dikutip dari literatur. Setelah data terkumpul, selanjutnya kemudian di analisis dengan menggunakan argumentasi hukum dan dengan logika berpikir deduktif induktif untuk mendapatkan jawaban dari permasalahan yang sedang diteliti. Hasil penelitian menunjukkan bahwa Hasil penelitian menunjukkan bahwa kedudukan Pos Bantuan Hukum (Posbakum) akan menjadi suatu sarana yang efektif untuk dapat menegakkan proses keadilan dan kepastian hukum bagi masyarakat untuk mencari keadilan terutama masyarakat yang tidak mampu (miskin), selanjutnya fungsi pemberian layanan bantuan hukum yaitu agar masyarakat mendapatkan pemahaman tentang hukum di pengadilan
\end{abstract}

Kata kunci: Kedudukan Posbakum; Fungsi Bantuan Hukum; Keadilan Hukum

\begin{abstract}
Law always has a reputation with the times, good law must be able to adapt its function according to the demands of the times. Not a few people lack knowledge of law. Therefore, legal aid activities, especially for people who cannot afford and laymen in the field of law, are increasingly widespread in society, which has now developed so much in Indonesia. The law that clearly regulates legal aid is Law Number 16 of 2011. This study aims to explain the position of the Legal Aid Post (Posbakum) in providing services at the Denpasar State Administrative Court and explain the function of providing legal aid services in Denpasar PTUN. The research method used is normative legal research, with the Legislative Approach. Sources of data used are primary legal materials and secondary legal materials such as statutory regulations, legal theory and can be quoted from the literature. After the data is collected, it is then analyzed using legal arguments and with the logic of inductive deductive thinking to get answers to the problems being studied. The results showed that the results showed that the position of the Legal Aid Post (Posbakum) would be an effective means of enforcing the justice process and legal certainty for the community to seek justice, especially those who are poor (poor), then the function of providing legal aid services is so that the public can get an understanding of the law in court
\end{abstract}

Keywords: Posbakum position; Legal Aid Function; Legal Justice

\section{PENDAHULUAN}

Pemerintah sebagai aparatur negara hendaknya dalam menjalankan tugasnya bertindak sesuai dengan norma hukum yang sudah mengatur serta bisa mengayomi masyarakatnya dengan sebaik-baiknya. Untuk itu diperlukannya pengawasan terhadap organ pemerintahan agar dalam melaksanakan tugasnya tidak berbuat seusai dengan kehendak sendiri. Dalam hukum administrasi yang penting adalah tindakan hukum, sebab suatu tindakan hukum akan menimbulkan akibat-akibat hukum tertentu bagi mereka yang terkena tindakan tersebut (Asyah, 2016).

Sebagaimana yang diketahui bahwa dalam masyarakat, kepentingan individu dan kepentingan sekelompok masyarakat saling berdampingan bahkan sering terjadinya benturan antara kepentingan tersebut sehingga menimbulkan terjadinya suatu sengketa, negara hukum menghendaki segala tindakan penguasa yang mempunyai dasar hukum yang jelas berdasarkan hukum tertulis maupun berdasarkan hukum tidak tertulis. Pada dasarnya negara hukum bertujuan untuk memberikan 
perlindungan hukum bagi setiap rakyatnya (Azhari, 2012). Salah satu bentuk perlindungan hukum terhadap rakyatnya ialah sebagaimana yang dapat kita ketahui bahwa dalam Pasal 24 ayat (2) UUD 1945 mengatur tentang kekuasaan kehakiman yang diselenggarakan olehMahkamah Agung dan Badan peradilan dibawahnya serta oleh Mahkamah Konstitusi.

Peradilan Tata usaha Negara (Peratun) sebagai salah satu lingkungan peradilan yang bertujuan untuk memberikan perlindungan hukum bagi rakyat sebagai pencari keadilan atas tindakan pemerintah yang sewenang-wenang. Sedangkan fungsi dari Pengadilan Tata Usaha Negara adalah melaksanakan pengawasan terhadap perbuatan pemerintah atau administrasi negara, agar dalam melaksanakan fungsinya senantiasa selaras dengan hukum, sehingga tidak merugikan hak-hak rakyat. Keberadaan Pengadilan Tata Usaha Negara ini merupakan suatu langkah untuk menghadapi kemungkinan adanya benturan atau perselisihan. Penjabaran makna perlindungan hukum bagi rakyatnya oleh Pengadilan Tata Usaha Negara salah satunya adanya kemudahan dalam bentuk pelayanan Pos Bantuan Hukum (Posbakum) (Fauzi \& Ningtyas, 2018).

Bantuan hukum adalah salah satu upaya mengisi hak asasi manusia terutama bagi masyarakat miskin di Indonesia. Oleh karena adanyaperkembangan hukum, kegiatan bantuan hukum khususnya untuk masyarakat yang tidak mampu serta awam di bidang hukum tampak semakin luas di kalangan masyarakat. Seperti yang telah diketahui bahwa keberadaan program pemberian layanan bantuan hukum adalah salah satu cara untuk mendapatkan keadilan bagi masyarakat yang tidak mampu. Oleh sebab itu, tujuan bantuan hukum perlu diperluas, tidak saja terbatas pada bantuan hukum individual, tetapi juga struktural. Karena masalah pelanggaran HAM seringkali menindas masyarakat miskin terutama yang berada di pedesaan. Karena itu, bantuan hukum harus diartikan sebagai salah satu upaya membebaskan masyarakat miskin dari struktur yang menindas mereka.

Beberapa peneliti terdahulu yang melakuan penelitian yang relevan dengan penelitian ini, yaitu Rosita, (2017) mengkaji tentang eksistensi pos bantuan hukum dalam memberikan bantuan hukum di Pengadilan Agama Kelas I-B Watampone. Peneliti lain mengungkapkan bahwa nilai sosial yang sifatnya memberikan informasi kepada masyarakat Bengkulu khususnya, dan masyarakat (bangsa) Indonesia umumnya mengenai manfaat daya guna Pemberian Bantuan Hukum terhadapmasyarakat tidak mampu (Prabowo, 2014). Dalam pelaksanaan pemberian layanan hukum oleh posbakum terhadap masyarakat kurang efektif, karena dipengaruhi oleh hambatan biaya (Rajagukguk, 2016). Namun deiketahui sampai saat ini masih terdapat masalah dalam pemberian bantuan hukum terhadap masyarakat, terutama pada masyarakat kurang mampu. Oleh sebab itu penelitian ini dilakukan bertujuan untuk menjelaskan kedudukan Pos Bantuan Hukum (Posbakum) dalam memberikan pelayanan di PTUN Denpasar dan menjelaskan fungsi pemberian layanan bantuan hukum di PTUN Denpasar

\section{METODE PENELITIAN}

Metode penelitian yang digunakan adalah penelitian hukum normatif, dengan pendekatan PerundangUndangan. Sumber data yang digunakan adalah bahan hukum primer dan bahan hukum sekunder seperti peraturan perundang-undangan, teori hukum dan dapat yang dikutp dari literatur. Setelah data terkumpul, selanjutnya kemudian di analisis dengan menggunakan argumentasi hukum dan dengan logika berpikir deduktif induktif untuk mendapatkan jawaban dari permasalahan yang sedang diteliti (Sugiyono, 2013). Bahan hukum primer diperoleh melalui pemahaman dengan membaca dan menganalisis UU Nomor 5 Tahun 1986 diadakan perubahan dengan UU Nomor 9 Tahun 2004 dan perubahan kedua UU Nomor 51 tahun 2009 tentang PERATUN dan UU Nomor 16 Tahun 2011 tentang Bantuan Hukum. Bahan hukum sekunder diperoleh melalui pengkajian kepustakaan (Library Reseach) yakni dengan membaca buku-buku hukum dan juga sumber dari internet yang berhubungan dalam permasalahan ini.

\section{HASIL DAN PEMBAHASAN \\ 1. Kedudukan Pos Bantuan Hukum (Posbakum) dalam Memberikan Pelayanan di PTUN Denpasar}

Eksistensi berasal dari kata bahasa latin yaitu existere yang berarti muncul, ada, timbul, memiliki keberadaan aktual, kedudukan, ataupun fungsi. Sedangkan bantuan hukum merupakan suatu media yang dapat digunakan oleh semua orang dalam rangka menuntut haknya atas adanya perlakuan yang tidak sesuai dengan kaedah hukum yang berlaku. Hal ini didasari oleh arti pentingnya perlindungan 
hukum bagi setiap manusia sebagai subyek hukum untuk dapat menjamin adanya penegakan hukum yang baik. Bantuan hukum itu bersifat membela masyarakat terlepas dari latar belakang, etnisitas, asal usul, keturunan, warna kulit, ideologi, keyakinan politik, kaya miskin, agama, dan kelompok orang yang dibelanya.

Posbakum adalah suatu pusat layanan yang dibentuk oleh setiap pengadilan agar dapat memberikan layanan hukum berupa informasi, konsultasi, dan advis hukum, serta pembuatan dokumen hukum yang dibutuhkan. Frans Hendra Winarta menyatakan bahwa, "bantuan hukum merupakan jasa hukum yang khusus diberikan kepada fakir miskin yang memerlukan pembelaan secara cuma-cuma, baik di luar maupun di dalam pengadilan, secara pidana, perdata dan tata usaha negara, dari seseorang yang mengerti seluk beluk pembelaan hukum, asas-asas dan kaidah hukum, serta hak asasi manusia". Posbakum merupakan pusat layanan bantuan hukum berupa pemberian informasi, konsultasi, advis dan pembuatan surat gugatan atau permohonan di PTUN, sejak lahirnya UU Nomor 16 Tahun 2011 tentang Bantuan Hukum.

Posbakum merupakan salah satu kebijakan pemerintah untuk memberikan layanan hukum bagi masyarakat yang kurang mampu (miskin), sekaligus sebagai bentuk konsekuensi negara Indonesia sebagai negara hukum. Terbitnya UU Nomor 16 tahun 2011 tentang bantuan hukum adalah jawaban bahwa negara Indonesia dalam mendukung terwujudnya akses kemudahan hukum bagi masyarakat miskin sesuai prinsip Hak Asasi Manusia. Sebagaimana dipaparkan sebelumnya, kehadiran Posbakum sebagai tempat layanan hukum disetiap pengadilan, termasuk Pengadilan Tata Usaha Negara Denpasar memiliki peran yang sangat strategis dalam memberikan layanan bantuan hukum. Hal ini dikarenakan Posbakum merupakan pemberi layanan bantuan hukum pertama yang mendekatkan akses hukum dan keadilan bagi masyarakat miskin.

\section{Fungsi Pemberian Layanan Bantuan Hukum di PTUN Denpasar}

Dalam pasal 28 d menyebutkan bahwa negara menjamin, melindungi, dan memberikan kepastian hukum yang adil dan perlakuan yang sama dihadapan hukum. Pasal 27 ayat (1) menyebutkan bahwa fakir miskin memiliki hak konstitusi untuk diwakili dan dibela oleh negara melalui advokat atau pembela umum (legal service), sehingga jaminan setiap orang untuk mendapat perlakuan yang sama di hadapan hukum sebagai pencerminan asas equality protection, maka negara telah mengeluarkan UU Nomor 16 Tahun 2011 tentang Program Bantuan Hukum (UUBH), dalam pasal 1 menyatakan bahwa pemberian bantuan hukum adalah jasa hukum yang diberikan oleh pemberi bantuan hukum secara cuma-cuma kepada penerima bantuan hukum, yaitu masyarakat miskin. Selanjutnya dalam pasal 1 angka 3, dalam SEMA No. 10 Tahun 2010 tentang Pedoman Bantuan Hukum menjelaskan bahwa Pos Bantuan Hukum (Posbakum) adalah ruang yang disediakan di setiap Pengadilan, termasuk PTUN Denpasar yang bertujuan untuk membantu dan membela masyarakat miskin demi mendapatkan keadilan. Kehadiran Posbakum saat ini disebut sebagai sebuah terobosan penting yang merupakan pengembangan dari konsep-konsep bantuan hukum yang telah dilakukan pemerintah sebelumnya. Keberadaannya merupakan bentuk implementasi tanggung jawab negara Indonesia sebagai negara hukum. Keberadaan Pembentukan Posbakum dilakukan oleh Mahkamah Agung (MA) disetiap pengadilan tingkat pertama dalam memberikan layanan bantuan hukum. Untuk tertibnya pelaksanaan pemberian bantuan hukum, khususnya mereka yang menempati Posbakum di dalam suatu pengadilan, seharusnya dilakukan oleh tenaga-tenaga yang profesional. Hal ini dimaksudkan agar tujuan pemberian bantuan hukum bagi masyarakat miskin tercapai.

Sesuai dengan hasil wawancara dengan petugas posbakum di PTUN Denpasar yaitu dengan Bapak Ida Bagus Suteja Putra, SH dan Bapak Ida Bagus Nyoman Bala Nugraha, SH selaku advokat di PTUN Denpasar, dapat disimpulkan bahwa kedudukan pos bantuan hukum (Posbakum) ialah sebagai berikut:

1. Memberikan informasi tentang tugas serta kedudukan Pengadilan Tata Usaha Negara Denpasar, ketika adanya masyarakat yang ingin mengajukan gugatan ke PTUN Denpasar agar mengerti dengan jelas tentang kewenangan PTUN Dernpasar dalam hal kepastian obyek sengketa agar tidak salah ketika mengajukan gugatan, misalnya seringkali gugatan dengan objek sengketa Sertifikat Hak Atas Tanah, yang seharusnya diselesaikan terlebih dahulu di Pengadilan Perdata mengenai sengketa kepemilikannya akan tetapi justru diajukan ke PTUN Denpasar, sedangkan sesungguhnya yang berwenang untuk menyelesaikan sengketa tersebut ialah keabsahan sertifikat hak atas tanah tersebut. 
2. Tugas posbakum yang lain adalah terkait dengan permohonan bantuan hukum lebih ditujukan kepada masyarakat yang tidak mampu (masyarakat miskin) untuk mendapatkan perlakuan secara layak dan mandiri dengan syarat disertai keterangan dari Lurah atau Kepala Desa setempat yang menyatakan bahwa yang bersangkutan memang tidak mampu (miskin), baru kemudian akan dinilai oleh Pengadilan apakah permohonan tersebut layak atau tidak untuk dibebaskan dari biaya perkara (permohonan beracara dengan Cuma-Cuma/Prodeo) ketika sengketa tersebut nantinya akan disidangkan di Pengadilan Tata Usaha Negara Denpasar.

3. Apabila permohonan beracara cuma-cuma (prodeo) yang dimohonkan oleh warga masyarakat dinyatakan layak oleh Pengadilan maka Posbakum akan berperan untuk membantu masyarakat tersebut nantinya ketika bersidang di Pengadilan Tata Usaha Negara Denpasar.

Adapun Petunjuk Pelaksanaan Peraturan Mahkamah Agung Republik Indonesia Nomor 1 Tahun 2014 Tentang Pedoman Pemberian Layanan Hukum Bagi Masyarakat tidak mampu di Pengadilan diatur dalam:

1. Undang-Undang Dasar Negara Republik Indonesia Tahun 1945Pasal 27 ayat (1).

2. Undang-Undang Nomor 39 Tahun 1999 tentang Hak Asasi ManusiaPasal 4.

3. Undang-Undang Nomor 18 Tahun 2003 tentang AdvokatPasal 22 ayat (1).

4. Undang-Undang Nomor 48 Tahun 2009 tentang Kekuasaan Kehakiman.

Masyarakat yang kurang mampu serta awam pengetahuannya dalam hukum yang ingin mengajukan perkaranya ke pengadilan seringkali dihadapkan pada aturan dan bahasa hukum yang sulit di mengerti. Baik pada tahap litigasi maupun non litigasi yang keseluruhannya harus dilakukan sesuai peraturan hukum yang berlaku, apabila permohonan dinyatakan tidak dapat diterima (niet ontvan kelijkeverklard) atau bahkan ditolak oleh majelis hakim di pengadilan padahal hanya karena permohonan tersebut tidak memenuhi aspek prosedural hukum. Berdasarkan UUD1945 dalam ketentuan Pasal 28 d ayat (1) menyatakan dengan tegas bahwa "setiap orang berhak atas pengakuan, jaminan, perlindungan, dan kepastian hukum yang adil serta perlakuan yang sama di hadapan hukum."

Bantuan hukum akan sangat bermanfaat jika diberikan oleh orang yang memahami hukum. Pelaksanaan pemberian bantuan hukum menurut Undang-Undang Bantuan Hukum hanya dilakukan oleh pemberi bantuan hukum yang telah memenuhi persyaratan. Persyaratan untuk dapat disebut sebagai pemberi bantuan hukum antara lain berbadan hukum, terakreditasi, memiliki kantor yang tetap, memiliki pengurus, dan mempunyai program bantuan hukum.Sering sekali bantuan hukum diasosiasikan oleh masyarakat sebagai belas kasihan bagi si miskin. Seharusnya, bantuan hukum jangan hanya dilihat dalam arti yang sempit tetapi juga dalam arti yang luas. Selain membantu orang miskin bantian hukum juga merupakan gerakan moral yang memperjuangkan Hak Asasi Manusia (HAM) (Lamarani, 2014).

Adapun persyaratan pemberian bantuan hukum untuk dapat memperoleh Bantuan Hukum, pemohon bantuan hukum harus memenuhi syarat sebagai berikut :

1. Mengajukan permohonan secara tertulis identitas Pemohon

2. Menyerahkan dokumen yang berhubungan dengan perkara.

3. Melampirkan surat keterangan miskin dari lurah / kepala desa.

4. Surat Keterangan Tunjangan Sosial lainnya seperti KKM, Jamkesmas, dan yang lainnya.

5. Surat Pernyataan tidak mampu membayar jasa advokat yang dibuat dan ditandatangani oleh Pemohon Bantuan Hukum dan diketahui oleh Ketua PTUN Denpasar (Mustafa, 2011).

Penerapan pemberian bantuan hukum bagi rakyat tidak mampu, tidak hanya sebatas memenuhi kebutuhan masyarakat akan pendampingan dalam setiap proses hukum di pengadilan, tetapi juga menjadikan masyarakat untuk dapat mengerti hukum secara jelas.

\section{SIMPULAN DAN SARAN}

\section{Simpulan}

Berdasarkan uraian pembahasan yang telah dijelaskan diatas, hasi penelitian dapat disimpulkan bahwa Diperlukan adanya itikad baik dari aparat penegak hukum dan para pencari keadilan untuk dapat memanfaatkan akses keadilan melalui pelayanan Pos Bantuan Hukum (Posbakum) di Pengadilan Tata Usaha Negara tersebut. Dengan adanya sinergi tersebut, maka kedudukan Pos Bantuan Hukum (Posbakum) akan menjadi suatu sarana yang efektif untuk dapat menegakkan proses keadilan dan kepastian hukum bagi masyarakat untuk mencari keadilan terutama masyarakat yang tidak mampu 
(miskin), yang kedua fungsi pemberian layanan bantuan hukum yaitu agar masyarakat mendapatkan pemahaman tentang hukum di pengadilan. Selain itu mereka juga bisa menghemat uang, waktu dan tenaga dengan adanya layanan bantuan hukum dari Posbakum ini. Pengadilan tentu sangat terbantu dengan adanya layanan pemberian bantuan hukum ini karena masyarakat yang datang ke persidangan biasanya sudah memiliki dan mempersiapkan dokumen-dokumen yang dibutuhkan, dengan harapan proses berperkara bisa lebih lancar agar tercapai asas sederhana, cepat dan biaya ringan.

\section{Saran}

Adapun yang disarankan peneliti terkait penelitian ini adalah diharapkan kepada aparatur pengadilan dapat membantu kinerja Pos Bantuan Hukum (Posbakum) terutama dalam bentuk sosialisasi atau pemberian pemahaman kepada masyarakat khususnya yang tidak mampu mengingat keberadaan posbakum sendiri kenerjanya sangat terbatas oleh waktu, yaitu di Posbakum Pengadilan Tata Usaha Negara Denpasar hanya masuk setiap hari senin dan kamis saja, sedangkan diluar hari tersebut tidak dapat terakomodir, apabila ada masyarakat yang memerlukan bantuan hukum kepada posbakum, yang kedua agar kiranya keberadaan Posbakum di Pengadilan Tata Usaha Negara Denpasar juga harus ditunjang dengan sarana dan prasarana yang memadai misalnya selain adanya buku catatan atau buku register juga harus ditunjang dengan adanya fasilitas komputer dan printer agar ketika masyarakat meminta data dan kejelasan tentang permasalahannya bisa diberikan dalam bentuk data yang jelas bukan sekedar penjelasan dalam bentuk lisan, sehingga masyarakat dapat lebih mengerti serta memahami dengan baik.

\section{DAFTAR PUSTAKA}

Asyah, N. (2016). Eksistensi Perlindungan Hukum Warga Negara Terhadap Tindakan Pemerintah dalam Membuat Keputusan Administrasi Negara. Jurnal Hukum Samudra Keadilan, 2(1), 44-54.

Azhari, A. F. (2012). Negara Hukum Indonesia: Dekolonisasi dan Rekonstruksi Tradisi. Jurnal Hukum Ius Quia Iustum, 19(4), 489-505.

Fauzi, S. I., \& Ningtyas, I. P. (2018). Optimalisasi Pemberian Bantuan Hukum Demi Terwujudnya Access to Law and Justice Bagi Rakyat Miskin. Jurnal Konstitusi, 15(1), 50-71.

Lamarani, H. F. (2014). Pemberian Bantuan Hukum Pada Masyarakat Kurang Mampu oleh Pemerintah. Lex Administratum, 2(3), 19-29.

Mustafa, B. (2011). Sistem Hukum Administrasi Negara Indonesia. Citra Aditya Bakti.

Prabowo, A. (2014). Peran Pos Bantuan Hukum (Posbakum) di Pengadilan Agama Bengkulu Kelas I A Berdasarkan Peraturan Mahkamah Agung Republik Indonesia Nomor 1 Tahun 2014. Jurnal Qiyas, 2(2), 197-209.

Rajagukguk, T. (2016). Efektifitas Pos Bantuan Hukum Pengadilan Sebagai Pemberi Layanan Bantuan Hukum Cuma-Cuma pada Perkara Pidana pada Pengadilan Negeri Pekanbaru. Jurnal Fakultas Hukum, 3(1), 1-15.

Rosita. (2017). Eksistensi Pos Bantuan Hukum dalam Memberikan Bantuan Hukum di Pengadilan Agama Kelas I B Watampone. 16(1), 250-260.

Sugiyono. (2013). Metode Penelitian Pendidikan Pendekatan Kuantitatif dan Kualitatif. Alfabeta. 